\title{
ИСТОРИЧЕСКИЕ ЗАПИСКИ
}

DOI: $10.17805 /$ zpu.2016.3.15

\section{К вопросу о переоснащении теоретико-методологического аппарата исторической науки}

\author{
С. В. ГОРЮНКОВ
}

(ОБЩЕСТВЕННЫЙ РЕГИОНАЛЬНЫЙ КОГНИТОЛОГИЧЕСКИЙ ЦЕНТР, Г. САНКТ-ПЕТЕРБУРГ)

В статье рассматривается проблема научного качества исторического образа мышления. Суть проблемы, как показывает эмпирический материал, заключается в том, что теоретическое обоснование так называемого принципа историзма скрыто содержит в себе «родовой ген» тавтологического понимания идеи развития.

Настоящего интереса к данной проблеме не наблюдается, ее комплексной разработки не существует. Есть лишь разрозненные наблюдения теоретико-методологического характера, принадлежащие ученым самого разного профиля. Они либо рассыпаны по статьям и монографиям узкоспециальной направленности, либо принадлежат авторам, работы которых по тем или иным причинам (идеологическим, конъюнктурным и др.) задвинуты на периферию научного внимания.

Как следствие, методологическая ситуация в исторической науке лишена четкого языка описания. С одной стороны, имеет место инерционная приверженность массового научного сознания устаревшим, но сохраняющим видимость научности, предпосылочным установкам. С другой стороны, наблюдается возрастающий интерес к эмпирически выверенной, но не имеющей пока еще под собой полноценного теоретического обоснования фактологии. А противоречие между этими двумя подходами начинает постепенно осознаваться как проявление кризиса методологии исторических исследований.

Преодоление кризиса предлагается начать с операционализации языка его описания - с переоснащения теоретико-методологического инструментария исторической науки в когнитивистском направлении. Проще же говоря, методологической альтернативой тем априорным и тавтологическим суждениям, которые до сих пор выдаются и принимаются за принцип историзма, должна послужить опора на эмпирический материал по исторической семантике ментально-языковых структур.

Ключевые слова: историческая наука; методология истории; наивный исторический объективизм; принцип историзма; эмпирическое обобщение

\section{ВВЕАЕНИЕ}

B предисловии к справочному изданию 2014 г. «Теория и методология исторической науки. Терминологический словарь», ответственным редактором которого выступил академик А. О. Чубарьян, мы читаем: «Процессы снижения статуса 
исторической науки, девальвация ремесла и соответственно профессионального языка историка, общие для мирового научного сообщества, для отечественной историографии оказались отягощены самими условиями ее бытования в последние три десятилетия» (От редколлегии, 2014: 6).

При всей внешней сдержанности этих слов очень трудно не увидеть в них признания факта глубокого кризиса предпосылочных оснований исторической науки. А если учесть, что методологический стержень этих оснований - так называемый историзм - выполняет функцию принципа познания, общего для представителей и гуманитарных, и естественных наук, то в тех же словах можно будет увидеть признание и того, что кризис является общенаучным. Но тогда и преодоление кризиса должно начинаться с операционализации (эмпирической интерпретации) языка его описания (Новейший философский словарь, 1998: 487-488). Ведь «уровень науки определяется тем, насколько она способна на кризис своих основопонятий» (Хайдеггер, 2006: 9).

Основопонятия, которыми пользуются историки, - не исключение. «В профессиональном сообществе сложилось устойчивое представление о парадигмальном характере происходящих изменений в исторической науке, нередко описываемых как “революция в историографии”. Особенно рельефно это отражает текущий процесс теоретико-методологического переоснащения научного знания...» (От редколлегии, 2014: 5).

\section{НАИВНЫЙ ИСТОРИЧЕСКИЙ ОБЪЕКТИВИЗМ}

По устоявшейся общенаучной традиции следование методологическим требованиям сводится обычно к равнению ученых самого разного профиля на некую, максимально авторитетную для них, концептуальную «планку», соответствие которой и принимается за критерий научности тех или иных артефактов, суждений и гипотез более частного характера. Формулу именно такого понимания методологизма дал А. Н. Уайтхед. Этот видный английский философ, говоря о «методе, порождающем значимое знание», пояснил его как необходимость опоры на «связную логическую и необходимую систему общих идей, в терминах которой можно было бы интерпретировать каждый элемент нашего опыта» (Уайтхед, 1990: 272).

В академической науке советского периода общенаучной концептуальной «планкой», или связной логической и необходимой системой общих идей, служило мировоззрение научного материализма в его марксистской интерпретации. И это же мировоззрение, уже без ссылок на марксизм, продолжает определять стиль мышления подавляющего большинства современных российских (как, впрочем, и западных) ученых.

Но вот проблема: именно о научном материализме В. И. Вернадский (не только выдающийся геобиохимик, но также профессиональный историк науки) отзывался как о философском течении, «которое было живым в конце XVIII, середине XIX века и которое в тех проявлениях, в каких оно выражается в науке, является историческим пережитком...» (Вернадский, 1989: 112).

Это нестандартное мнение можно было игнорировать - и игнорировалось в советское время. Но сегодня продолжать замалчивать вопрос о том, что конкретно Вернадский имел в виду, становится просто неприлично. Тем более что ответ очевиден: материализм как целостное и связное научное мировоззрение воз- 
ник не в процессе осмысления полученных опытным путем данных, а в порядке выведения логических следствий из преждевременно принятой за аксиому посылки.

За саму посылку была принята разработанная идеологами XVI-XVIII вв. (Ж. Бодэн, А. Аокк, А. Тюрго, Ж. Кондорсэ и Ар.) концепция прогресса, восходящая, в свою очередь, к более ранним религиозно-утопическим концепциям. Средством же придания посылке видимости строгого методологического принципа послужила чисто условная, откровенно механистическая и абсолютно несостоятельная в научном плане схема развития «от простого к сложному», «от низшего к высшему».

Вся остальная материалистическая «научность», объясняющая историческую динамику природных и социальных процессов, - это просто итог доведения «прогрессистско-усложненческой» схемы развития до ее логического завершения путем последовательного наращивания на нее соответствующих ментальных конструкций. Решающий вклад сюда внесла, конечно же, дарвиновская теория әволюции, хотя самим автором теории несостоятельность дивергентной схемы развития осознавалась изначально. «Знаю, - писал Ч. Аарвин, - что едва ли возможно определить ясно, что разумеется под более высокой или более низкой организацией»; «это область очень запутанного вопроса» (Аарвин, 1933: 359, 629). Аа и профессиональные оппоненты Аарвина из числа его современников тоже понимали, что его теория - не столько биологическое, сколько философское учение, вершинное проявление механистического материализма (так, например, считал H. Я. Аанилевский, и не только он).

Тем не менее именно дарвиновская теория послужила естественно-научной основой для историко-материалистической трактовки развития общества - это видно из писем К. Маркса Аассалю и Энгельсу. А на стыке двух теорий - Аарвина и Маркса выстроилась со временем логическая цепочка: «биологическая әволюция $\rightarrow$ антропо- и культурогенез $\rightarrow$ социальный прогресс», еще позже дополненная теориями абиогенеза и Большого взрыва и легшая в основу мировоззренческой парадигмы современного научного образа мышления - эволюционно-исторической картины мира.

Эта-то «связная логическая и необходимая система общих идей», ни одно из звеньев которой до сих пор научно не доказано, и является теоретическим фундаментом научно-материалистической версии принципа историзма - требования рассматривать каждое явление истории с точки зрения его возникновения и дальнейшего развития. Принципу с самого начала постарались придать товарный вид, завернув грубую механистическую болванку в респектабельную «диалектическую упаковку». А профессиональные пиар-технологии, заточенные под пропаганду социальных революций, обеспечили ему устойчивый общественный спрос.

Все остальное доделала система среднего и высшего образования, на протяжении нескольких десятилетий внедрявшая эволюционно-историческую картину мира в ученые и неученые головы. Как следствие, скрытая методологическая ущербность этой картины самым непосредственным образом отражается на качестве современного массового, в том числе научного, сознания. Аостаточно сказать, что эволюционно-историческое мировоззрение до сих пор устойчиво ассоциируется не с гипотетическим допущением, отразившим уровень развития научной мысли XVIII-XIX вв., а - в духе эволюционного позитивизма Г. Спенсера - с самой «объективной реальностью». 
И не имеет по большому счету никакого значения критика отдельных элементов картины, когда кто-то смеется над теорией Аарвина, кто-то не приемлет учения Маркса, а кто-то не верит в абиогенез или даже в Большой взрыв. Эволюционно-историческое мировоззрение давно уже живет собственной жизнью бессознательной предпосылки, задающей все остальные следствия из нее: от объяснения мировых процессов и оправдания глобальных социально-политических экспериментов до «само собой разумеющихся» штампов научного стиля мышления.

Но поэтому и не удивительно, что этот стиль мышления все чаще начинает осознаваться как «наивный методологизм», «наивный историзм» и «наивный исторический объективизм» (Гадамер, 1988: 354, 581-584).

\section{МЕТОАОАОГИЧЕСКАЯ АИЬТЕРНАТИВА}

Подлинно научную альтернативу наивному историческому объективизму способны составить лишь те формы опытно-оправданного знания, которые В. И. Вернадский называл «эмпирическими обобщениями». Напомню, что это выражение он ввел в научный оборот с целью предельно четкого разграничения эмпирическивыверенного знания и философского мировоззрения. Второе, как он писал, «может даже мешать научной работе и научному творчеству, так как оно неизбежно закрепляет научные ошибки данного времени, придает временным научным положениям больше достоверности, чем они в действительности имеют» (Вернадский, 1989: 431).

А вот соображения Вернадского о «чистой эмпирике»: «Правильным является... стремление, все более и более преобладающее в научных исканиях... подходить к изучению явлений жизни чисто эмпирически, считаться с невозможностью дать ей “объяснение”, т. е. дать ей место в нашем абстрактном космосе, научно построенном из моделей-гипотез» (Вернадский, 1967: 237-238; курсив мой. - С. Г.).

Как видим, аргументом в пользу истинности эмпирически-оправданных научных обобщений Вернадский считал как раз их необычность, их несовместимость с господствующими философскими установками. «Эмпирическое обобщение, писал он, - раз оно точно выведено из фактов, не требует проверки. Оно может существовать и быть положено в основу научной работы, даже если оно является непонятным и противоречит господствующим теориям и гипотезам» (Вернадский, 1975: 71). То есть не нужно, считал он, заботиться о согласии или несогласии эмпирического обобщения с другими существующими представлениями о природе, «их совпадение с нашими научными представлениями о природе нас не интересует, их противоречие с ними составляет научное открытие» (Вернадский, 1967: 238).

Из такого хода мысли вовсе не следовало, что Вернадского не интересовала проблема целостного и связного знания. «Эмпирическое обобщение, - читаем в его труде «Биосфера», - может очень долго существовать, не поддаваясь никаким гипотетическим объяснениям, являться непонятным и все же оказывать огромное благотворное влияние на понимание явлений природы. Но затем часто наступает момент, когда оно вдруг начинает освещаться новым светом, становится областью создания гипотез, начинает менять наши схемы мироздания и само меняться. Очень часто тогда оказывается, что в эмпирическом обобщении мы имели не то, что думали, или имели в действительности много больше, чем думали» (там же). 
Исходя из таких методологических установок, Вернадский радикально пересмотрел всю традиционную аксиоматику, связанную с проблемами абиогенеза и эволюции: «Научно вопрос о появлении жизни на земле... сводится к вопросу о начале в ней биосферы. И только в этой форме он должен сейчас изучаться. Вне биосферы мы жизнь научно не знаем и проявлений ее научно не видим» (Вернадский, 1931: 634). Эволюционный же процесс, «какую бы его форму мы ни взяли, всегда идет уже внутри биосферы, т. е. в живой готовой природе» (там же: 648).

\section{СЮРПРИЗЫ ЭМПИРИЧЕСКИХ ОБОБЩЕНИЙ}

Все сказанное Вернадским о методологической ситуации в области изучения природы целиком применимо и к ситуации в области изучения социальной истории. 3десь накоплен внушительный объем противоречащих требованиям классического историзма эмпирических обобщений, связанных с попытками понять истинную природу социальной динамики. Взять хотя бы те, абсолютно не совместимые с идеей «прогресса в сознании», модели развития, посредством которых все чаще осмысляется история культуры. Здесь и модель перевода бессознательно-мифологических форм коллективного мышления в их осознанно-рефлексивные формы (Г. Юнг), и модель преобразования символов-образов в символы-понятия (О. М. Фрейденберг), и модель «трансформации инварианта» (В. В. Иванов, В. Н. Топоров), и разнообразные «диалогические» модели (М. М. Бахтин, А. Тойнби). Не говорю уже о том, что сама этимология слова «развитие» указывает на исходный смысл понятия не как на процесс усложнения некой исходной «простоты», а как на нечто неотделимое от идеи «развивания», предполагающей существование изначально сложной «свитости», «свернутости» того, что развивается (Ааль, 1996: 18).

Эмпирический материал такого рода целиком вписывается в тенденцию неклассического решения проблемы происхождения языка - универсального интерпретанта культуры. Так, уже В. Гумбольдт понимал: «...каким бы естественным ни казалось предположение о постепенном образовании языков, они могли возникнуть лишь сразу. Человек является человеком только благодаря языку, а для того чтобы создать язык, он уже должен быть человеком (фиксация очень важного с методологической точки зрения момента тавтологии. - С. Г.). Когда предполагают, что этот процесс происходил постепенно, последовательно и как бы поочередно, $<\ldots>>$ то упускают из виду нераздельность человеческого сознания и человеческого языка, не понимают природу действия рассудка, необходимого для постижения отдельного слова и вместе с тем достаточного для понимания всего языка» (Гумбольдт, 1984: 314).

Зафиксируем еще один, очень важный с методологической точки зрения, момент: в своем понимании сущности языка В. Гумбольдт бессознательно для самого себя исходил из двух диаметрально противоположных установок (довольно частый в научной практике случай, оборачивающийся эклектичностью суждений). Глубоко чувствуя системную специфику языка, он не мог не признавать его изначальной целостности, чем и объясняется вышеприведенное высказывание. А как типичный представитель «просвещенческой школы», он не мог принять идеи изначальной «предзаданности» языка. Отсюда - его версия глоттогенеза, противоречащая сказанному выше: «Язык невозможно представить себе как нечто заранее данное $<. . .>$ Язык с необходимостью возникает из человека, и, конечно, мало- 
помалу, но так, что его организм не лежит в виде мертвой массы в потемках души, а в качестве закона обусловливает функции мыслительной деятельности человека; следовательно, первое слово уже предполагает существование всего языка» (там же).

Более поздняя научная мысль попыталась преодолеть противоречие между двумя диаметрально противоположными установками путем отказа от той, что оборачивается тавтологией. Например: «В. Томсен в “Истории языковедения до конца XIX века” сообщает, что “парижское лингвистическое общество в своем уставе (от 1865 года) решительно исключает проблему происхождения языка из числа предметов, которые могут быть в нем предметом обсуждения” 》 (Якушин, 1985: 66). «В книге “Язык. Аингвистическое введение в историю” Ж. Вандриес энергично доказывает абсолютную невозможность реконструировать не только процесс происхождения языка, но и начальные этапы его развития. "Мысль о том, что путем сравнения существующих языков можно восстановить первичный язык”, он называет химерой. Изучение языков диких племен также ничего не дает, так как их языки столь же сложны, как и языки цивилизованных народов. Аетский язык есть результат искажения или имитации языка взрослых. Он “укажет лишь, как усваивается уже организованный язык, но он не сможет объяснить, чем мог быть язык в начале своего развития"» (там же).

Еще дальше пошел создатель теории символических форм Э. Кассирер. В своем главном труде он писал: «Вместо того, чтобы подразумевать под “происхождением” мифологическую потенцию, мы начинаем видеть в нем научный принцип и именно как таковой учимся его понимать» (Кассирер, 2002: 32). И о том же, по сути, говорил В. И. Вернадский, считавший, что абсолютно все гипотезы о происхождении Вселенной, Земли, Жизни и т. А. имеют своим основанием не объективную логику независимой научной мысли, а мифорелигиозную идею «Начала Мира», исторически унаследованную позднейшей философией и наукой. «В европейско-американскую науку, - писал он, - это было внесено... Иммануилом Кантом (1724-1804) в введенном им понятии естественного тела или естественного процесса в конце XVIII или начале XIX в. И мы сейчас видим, что ученые, связанные с другим настроем мыслей, связанные с Индией и отчасти Аальним Востоком, не видят никакой логической обязательности считать неизбежным при изучении научных явлений существование начала Мира, начала Вселенной, начала Жизни и т. п., так же как и их конца. Этот факт коренного различия в настрое научной мысли... ясно доказывает, что то, что кажется западноевропейским ученым логически неизбежным, - есть иллюзия и не вытекает из научных фактов, вывод, привнесенный в нашу мысль социальной обстановкой» (Вернадский, 1987: 313-314).

По форме и Кассирер, и Вернадский говорили об «историзме» как о поверхностно онаученной языковой презумпции «происхождения» («возникновения», «начала»). По сути же, они говорили о скрытой методологической ущербности самой идеи эволюционно-исторического развития как движения от некой исходной бессвязности и бесструктурности к связности и целостности. С их точки зрения данная идея оказывалась не более чем производным от мифа о зарождении порядка из хаоса «научным римейком» (см. название труда И. Пригожина «Порядок из хаоса»). И в этом смысле их позиция «работала» на эмпирически-оправдан- 
ную идею изначальной целостности и организованной сложности изучаемых явлений - идею, воплощенную в основных положениях общей теории систем (Берталанфи, 1969).

Аогадку об изначальной системной целостности культуры (универсальным интерпретантом которой, напоминаю, является язык) высказала в середине XX в. и О. М. Фрейденберг: «Нет такой ранней поры, когда человечество питалось бы обрывками или отдельными кусками представлений. В самые первые әпохи истории мы застаем человека с системным мировосприятием. Как в области материальной, так и общественной и духовной первобытный человек с самого начала системен, и в этом его коренное отличие от стадного животного. Чем древней культура, тем больше в ней внутренней связанности, неподвижности, замкнутости» (Фрейденберг, 2008: 34).

Эмпирическими обобщениями такого рода давно уже подготавдивается почва для осознания неизбежности новой постановки вопроса о начале культуры. То есть идея гипотетической «нулевой», пусть и сильно растянутой в историческом времени, точки отсчета, от которой якобы набирает обороты процесс усложнения культуры, начинает постепенно уступать место эмпирически оправданному представлению о «предпосылочном информационном фонде культуры» - о некоем исходном арсенале ее изобразительных средств и мировоззренческих установок. Смысловое тождество с таким «фондом» обнаруживают и «предструктура понимания» (Хайдеггер, 2006: 150-151), и «дорефлексивная инфраструктура неявных допущений» (Огурцов, 1999: 81), и «непроявленный семантический континуум» («Нельзя сказать что-либо серьезное о сознании, не постулировав изначальное существование непоявленной семантики», см.: Налимов, 2011: 299).

\section{СМЫСАОВОЕ ПОАЕ КУАЬТУРЫ}

Необычный взгляд на начало культуры - это лишь самый первый сюрприз, преподносимый эмпирическим взглядом на ее историю. Ничуть не меньшим сюрпризом оказалась научная несостоятельность представления, согласно которому характер мыслительного процесса у человека во все века был одним и тем же. Эмпирический материал засвидетельствовал другое: чем древнее данные по истории мышления, тем большее недоумение они вызывают (Горюнков, 2014: 40-67).

Очень долго такие данные рассматривались, да и сегодня нередко продолжают рассматриваться, как тупики, заблуждения, предрассудки и прочие издержки неразвитого сознания. В лучшем случае они принимаются за проявления «сакральных» ( "ритуальных», «магических», «культовых», «обрядовых» и т. А.) сторон общественной жизни, но по факту приравниваются к тем же предрассудкам и на общее понимание прошлого никак по большому счету не влияют. А между тем в науке накопилось достаточно много материала, свидетельствующего о том, что странности смысловой организации древних культур связаны не столько с отклонениями от «смысловой нормы», сколько с неприменимостью самого понятия «нормы» к истории смыслов.

Сначала такой ход мысли был зафиксирован в тезисе $\Lambda$. Аеви-Брюля о так называемом дологическом мышлении первобытного человека. А дальнейшими исследованиями вскрылась еще более интересная картина. В частности, К. Г. Юнгом было показано, что прежний человек «не более логичен или алогичен, чем мы, просто он 
думает и живет, исходя из совсем других предпосылок по сравнению с нами»; «различаются <...> только исходные [смысловые] предпосылки» (Юнг, 1993: 159-161). И к аналогичным выводам подвели работы К. Аеви-Стросса, показавшие, что сама по себе «логика мифологического мышления так же неумолима, как логика позитивная», а разница между древним и современным типами мышления заключается «не столько в качестве логических операций, сколько в самой [смысловой] природе явлений, подвергаемых логическому анализу» (Иеви-Стросс, 1985: 206).

Имелось в виду, что чисто формально логика применима к любым, даже самым абсурдным, смысловым конструкииям (вспомним силлогизм $\Lambda$. Кэрролла: все змеи крылаты / автор статьи - змей / следовательно, у него есть крылья). Но, к сожалению, Аеви-Стросс сам оказался не на высоте собственных эмпирических наблюдений: его выводы из них, как и выводы В. Гумбольдта, оказались эклектичными - исходящими одновременно из противоречащих друг другу предпосылок. Аело в том, что, как показал в своих работах этот нобелевский лауреат, мифологические смыслы качественно отличны от современных. Отсюда было рукой подать до признания того, что меняется в истории не логика естественных языков, а их смысловая структура, которой неизменная во времени логика оперирует. Но поскольку приоритетной методологической целью для Аеви-Стросса была не фиксация того, что есть в действительности, а - по его собственному признанию защита «дела материализма» (Иеви-Стросс, 2006: 34), то он пошел по другому пути. А именно: мифологическим смыслам он попросту отказал в праве называться смыслами, выдвинув абсолютно произвольный тезис, что «миф - это «язык... на котором смыслу удается, если можно так выразиться, отделиться от языковой основы, на которой он сложился» (Иеви-Стросс, 1985: 187). В логику же он «встроил» свое собственное, крайне искусственное и натянутое, содержание. «Верное понимание мифа, - заявил он, - не в каком-нибудь наделенном особыми преимуществами содержании. Оно состоит в логических отношениях, лишенных содержания» (Меви-Стросс, 2006: 228).

Ясно, что такой подход к проблеме, сводящий главные болевые точки истории культуры к надуманным оппозициям типа «сырое - вареное», «свежее - тухлое» и т. д., выдаваемым к тому же за инструмент разрешения противоречий, способен удовлетворить лишь таких же, как сам $е$ еви-Стросс, защитников «дела материализма». А за подлинно научную альтернативу его подходу приходится принимать эмпирически оправданную концепцию исторической изменчивости смыслового поля культуры. Чему и положил начало (в своей обычной противоречивой манере) все тот же В. Гумбольдт: «Время благодаря ускоренному развитию идей, нарастанию мыслительной силы и углублению и утончению чувственности часто придает ему [языку] черты, которыми он раньше не обладал. $B$ прежнюю [языковую] оболочку вкладьљается тогда другой смысл (курсив мой - С. Г.), под тем же чеканом выступает что-то иное, по одинаковым законам связи намечается иначе градуированный ход идей» (Гумбольдт, 1984: 106).

В начале XX в. взгляд на смысловые структуры естественных языков как на исторически изменчивые поддержал В. И. Вернадский, заметивший, что идея неизменности разума не отвечает действительности (Вернадский, 1988: 75), затем

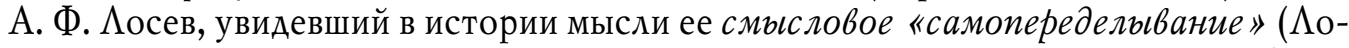
сев, 1983). А сегодня это направление мысли, становящееся постепенно все более 
актуальным, развивается в рамках тезаурусного подхода к изучению явлений мировой культуры. «На разных этапах и в различных исторических условиях, - пишет, например, Вал. А. Ауков, - одни и те же понятия могли менять свое содержание» (Ауков, 2008: Электронный ресурс).

«В широком, то есть в теоретико-методологическом плане, речь... идет... о том, что главным субъектом исторического процесса является смысловая структура естественных языков, и что одним из важнейших результатов этого процесса оказывается обретение языковыми значениями новых смыслов» (Горюнков, 2002: 108). А можно сказать и так, что история смыслов человеческой культуры оказывается историей перебора, перетряски, перекомбинирования внутриязыковых семантических связей. Образно, хотя и с сильным упрощением, такую историю можно сравнить с «перетасовкой колоды карт», где сама «колода» - это языковой тезаурус (или их совокупность), а взаимное расположение «карт» относительно друг друга - это отношения между образующими тезаурус языковыми значениями. Естественно, в ходе такой «перетасовки» (движущие силы которой - предмет отдельного разговора) отношения между «картами» должны изменяться самым радикальным образом (Горюнков, 2014: 43), порождая независимые от «значений» «смыслы» и спасая тем самым язык той или иной фазы развития культуры от шаблонизации и окостенения.

Феномен исторической изменчивости смысловой структуры естественных языков вступает в решительное противоречие с тем известным утверждением классиков исторического материализма, согласно которому у форм сознания нет собственной истории, нет развития. В то же время признанием этого феномена проливается свет на очень многое в загадках исторического смысловыражения. Например, объясняется огромное разнообразие характеров и типов коллективной ментальности в истории мировой культуры. Объясняется, почему слова древних текстов, внешне похожие на современные, обладают нередко отличным от современного смысловым содержанием. И, разумеется, объясняется, почему тексты тех или иных исторических эпох облекаются обычно не в «универсальные» семантические формы, а в такие, которые обусловлены специфическим языком своей эпохи, ее контекстом, ее «речестроем», ее «смысловым полем».

Парадоксально, однако, что эмпирический взгляд на исторически подвижную, перманентно изменяющуюся смысловую картину мира объясняет не только многие вещи, увеличивающие нашу способность их понимания, но также и вещи, уменьшающие ее. Например, наше взаимопонимание в этой ситуации начинает выглядеть как всего лишь взаимное узнавание сходных тезаурусных конструкиий (Горюнков, 2014: 141-144). И здесь остается надеяться лишь на неуклонно возрастающий интерес к метаязыковой проблематике, обещающей вернуть в поле научного зрения понятие смьслового инварианта (там же: 199-228)

\section{МИФ КАК АРЕВНЕЙШИЙ ТЕЗАУРУС}

Эмпирические данные по истории культуры все настойчивее вынуждают считаться с той очевидностью, что в истоках культуры лежит не «зародышевое», постепенно усложняющееся языковое сознание, а необычайно сложное и целостное мировоззрение в его наиболее ранних - мифологических - формах. Оказалось, что именно оно, это древнейшее мировоззрение, и дает начало всем позднейшим 
проявлениям культуры, от религии до науки, в том числе исторической (Токарев, Мелетинский, 1980). То есть мифы стало возможным понимать не как отдельную специфическую ветвь языкового смысловыражения, а как сам язык в его наиболее ранних формах - как древнейший способ организации его смысловой структуры. Что отметила уже О. М. Фрейденберг: «Рядом с мифом не могло быть в сознании не-мифа, какой-то непосредственно данной реальности; неверно, что существовали мифы сами по себе, только в одной области - в области воображения, а в другой, практической, человек трезво осознавал опыт и житейские акты, ел ради утоления голода, женился ради семьи и потомства, защищался от холода одеждой и выбирал правителей для охраны своих интересов» (Фрейденберг, 2008: 39).

Проще говоря, мифы оказались «нашим всем» - той самой «сокровищницей смыслов» (thesauros), игнорирование которой равнозначно игнорированию самой культуры. «Конкретная же картина того, каким образом из практики ритуальных измерений и числового “бриколажа” возникали ранние варианты математической науки, из мифопоэтических териоморфно-вегетативных классификаций возникала зоология и ботаника, из учения о космических стихиях и составе тела - медицина, из размыкания последнего этапа в текстах об акте творения - история, а из спекуляций над схемами мифопоэтических операций и лингвистического “бриколажа" - начала логики, языка науки (метаязыка) и лингвистики, - хорошо известна и многократно описана. Во всяком случае, древнегреческая натурфилософия в лице Гераклита, Пифагора, Анаксагора, история в лице Геродота, логика и математика в лице Аристотеля и Эвклида (и того же Пифагора) сохраняют живые связи с наследием мифопоэтической эпохи» (Топоров, 1982: 35). И «в еще большей степени то же самое можно сказать о том, что называют началами науки в Аревней Индии или Китае» (там же).

В свете такого понимания истории языковых смыслов становятся намного более понятными слова А. Ф. Аосева о том, что «мифом сознательно или бессознательно руководится всякая мысль, в том числе философская» (Иосев, 1993: 674). Как и слова Х.-Г. Гадамера о том, что «преодоление всех предрассудков, это наиболее общее требование Просвещения, само начинает разоблачать себя в качестве предрассудка» (Гадамер, 1991: 18). «Историко-понятийный анализ показывает, что лишь благодаря Просвещению понятие предрассудка получает привычную для нас негативную окраску. Само по себе слово “предрассудок" означает пред-суждение (Vorurteil), то есть суждение (Urteil), вынесенное до (vor) окончательной проверки всех предметно определяющих моментов» (Гадамер, 1988: 322-323).

\section{«КРУГ В АОКАЗАТЕАЬСТВАХ»}

Впрочем, главным сюрпризом явилась не столько реабилитация так называемых предрассудков, сколько невозможность объяснить происхождение древнейшей формы мировоззрения ссылками на некий предыдущий этап становления и усложнения культуры. Аело в том, что поскольку историческая наука сама оказалась производной от мифов, то стала очевидной бессмысленность объяснения происхождения мифов тем же самым, что от них и произошло (Горюнков, 1991). В методологии, как известно, такой способ объяснения считается не имеющим собственной доказательной силы и называется «порочным кругом» ( «ругом понимания», «кругом в доказательствах» и др.). 
Проблема «круга», скрывающаяся за внешней научной респектабельностью так называемого историзма, - это главная, хотя и не афишируемая сегодня, методологическая проблема современности. А не афишируется она потому, что фактом ее признания главной методологической проблемой современности рушится вся «просвещенческая» парадигма мышления - рассыпается тот «тавтологический песок», на котором наука XVIII-XX въ. воздвигла свою эволюиионно-историческую «вавилонскую башню» ( «бутафорский двореи научного миропонимания», см.: Флоренский, 1999: 104). Именно к проблеме «круга», предельно обнажающей наивный объективизм современного понимания прошлого, и сводится суть кризиса всего эволюционно-исторического миропонимания. Предельно ясно эту проблемную ситуацию охарактеризовал все тот же Гадамер: «Наивность так называемого историзма состоит в том, что он... полагаясь на методологизм своего подхода, забывает о своей собственной историчности. <...> Подлинно историческое мышление должно также мыслить и свою собственную историчность» (Гадамер, 1988: 354-355. Курсив мой. - С. Г.).

Усугубляется же методологический кризис незавершенностью своего осмысления: факт «круга» не отрицается, но и не афишируется, а следствия из него и вовсе остаются не выведенными.

\section{ЗАКАЮЧЕНИЕ}

Между тем эти следствия крайне важны. Аело в том, что на тавтологическую ситуацию нужно как-то реагировать: либо «выходить из круга», либо «правильно (по выражению М. Хайдеггера) в него входить». Но первый вариант - это всегда самообман, попытка проигнорировать проблему, «спрятать голову в научный песок», - что сплошь и рядом и происходит. А второй вариант вынуждает усматривать в «круге» «не колесо, в котором движется любой род познания» (Хайдеггер, 2006: 153), но острую необходимость заняться внутренним устройством той смысловой структуры, историческое изучение которой наталкивается на «круг».

Неизбежность принятия на вооружение второго варианта предвидел еще В. Я. Пропп. «Формальное изучение, - писал в одной из своих поздних работ этот выдающийся исследователь фольклорного метаязыка, - нельзя отрывать от исторического и противопоставлять их. Как раз наоборот: формальное изучение, точное систематическое описание изучаемого материала есть первое условие, предпосылка исторического изучения и вместе с тем первый шаг его» (Пропп, 1976: 139).

Формальным здесь названо структурное изучение тех древнейших способов смысловыражения, исторический взгляд на происхождение которых оборачивается «кругом». А право называться подлинно-историческим получает в ситуации «круга» лишь метаисторический взгляд на прошлое - взгляд, учитывающий наивно-объективистскую сущность традиционно понимаемого историзма.

\section{СПИСОК АИТЕРАТУРЫ}

Берталанфи, $\Lambda$. фон (1969) Общая теория систем - обзор проблем и результатов // Системные исследования : ежегодник. М. : Наука. 203 с. С. 36-37.

Вернадский, В И. (1931). Об условиях появления жизни на земле // Известия Академии наук СССР. VII серия. Отделение математических и физических наук. №5. C. 633-653. 
Вернадский, В. И. (1967) Биосфера. М. : Мысль. 376 с.

Вернадский, В. И. (1975) Размышления натуралиста : в 2 кн. М. : Наука. Т. 1. 177 с.

Вернадский, В. И. (1988) Философские мысли натуралиста. М. : Наука. 522 с.

Вернадский, В. И. (1987) Химическое строение биосферы Земли и ее окружения. М. : Наука. 339 с.

Вернадский, В. И. (1989) Начало и вечность жизни. М. : Советская Россия. 704 с.

Гадамер, Х.-Г. (1988) Истина и метод. Основы философской герменевтики : пер. с нем. M. : Прогресс. 704 с.

Гадамер, Х.-Г. (1991) Актуальность прекрасного : пер. с нем. М. : Искусство. 366 с.

Горюнков, С. В. (1991) О соотношении мифологии и онтологии (в свете идей В. И. Вернадского) // Ноосфера и художественное творчество : сб. ст. / отв. ред. Вяч. Вс. Иванов. M. : Наука. 280 с. С. $88-100$.

Горюнков, С. В. (2002) О герменевтике былин // Русская литература. № 1. С. 100-108.

Горюнков, С. В. (2014) Мета-коды культуры. СПб. : ООО Контраст. 304 с.

Гумбольдт, В. фон. (1984) Избранные труды по языкознанию : пер. с нем. М. : Наука. 398 c.

Ааль, В. (1996) Толковый словарь живого великорусского языка : в 4 т. СПб. : ТОО «Аиамант». Т. 4. 688 с.

Аарвин, Ч. (1939) Сочинения / под общ. ред. А. А. Берга, А. А. Борисяка, Н. И. Вавилова и др. М. -. : Изд-во Академии наук СССР. Т. 3.830 с.

Кассирер, Э. (2002) Философия символических форм : в 3 т. : пер. с нем. М. ; СПб. : Университетская книга. Т. 1. 272 с.

Аеви-Стросс, К. (1985) Структурная антропология : пер. с фр. М. : Наука. 536 с.

Иеви-Стросс, К. (2006) Мифологики: сырое и приготовленное : пер. с фр. М. : ИА «Фюид». 399 с.

Аосев, А. Ф. (1983) О значении истории философии для формирования марксистсколенинской культуры мышления // Алексею Федоровичу Аосеву: к 90-летию со дня рождения : сб. ст. / сост. В. В. Гогуадзе. Тбилиси : Изд-во Тбилис. ун-та. 170 с. С. 142-155.

Аосев, А. Ф. (1993) Очерки античного символизма и мифология. М. : Мысль. 959 с.

Иуков, Вал. А. (2008) Субъектная культурология [Электронный ресурс] // Информационный гуманитарный портал «Знание. Понимание. Умение». № 4. URL. http://www. zpu-journal.ru/e-zpu/2008/4/Lukov_culturology/ (дата обращения: 10.04.2016).

Налимов, В. В. (2011) Спонтанность сознания. Вероятностная теория смыслов и смысловая архитектоника личности. 3-е изд. М. : Академический проект ; Парадигма. 399 с.

Новейший философский словарь (1998) / под ред. А. А. Грицанова. Минск : Изд. В. М. Скакун. 896 с.

Огурцов, А. П. (1999) Социальная история науки: две стратегии исследований // Философия, наука, цивилизация / отв. ред. В. В. Казютинский. М. : Эдиториал УРСС. 368 с. C. $63-88$.

От редколлегии (2014) // Теория и методология исторической науки. Терминологический словарь / отв. ред. А.О. Чубарьян. М. : Аквилон. 576 с. С. 5-10.

Пропп, В. Я. (1976) Фольклор и действительность. Избранные статьи. М. : Наука. 326 с.

Токарев, С. А., Мелетинский, Е. М. (1980) Мифология // Мифы народов мира : в 2 т. М. : Советская энциклопедия. Т. 1. 672 с. С. 11-20.

Топоров, В. Н. (1982) Первобытные представления о мире (общий взгляд) // Очерки истории естественно-научных знаний в древности / отв. ред. А. Н. Шамин. М. : Наука. 279 с. С. $8-40$.

Уайтхед, А. Н. (1990) Избранные работы по философии : пер. с англ., общая ред. и вступ. ст. М. А. Кисселя. М. : Прогресс. 718 с. 
Флоренский, П. А. (1999) Соч. : в 4 т. / сост. игумена Андроника (А. С. Трубачёва), П. В. Флоренского, М. С. Трубачёвой; ред. игумен Андроник (А. С. Трубачёв). М. : Мысль. Т. 3 (1). 621 с. 896 c.

Фрейденберг, О. М. (2008) Миф и литература древности. Екатеринбург : У-Фактория.

Хайдеггер, М. (2006) Бытие и время : пер. с нем. СПб. : Наука. 451 с. $336 \mathrm{c.}$

Юнг, К. Г. (1993) Проблемы души нашего времени : пер. с нем. М. : Прогресс ; Универс.

Якушин Б. В. (1985) Гипотезы о происхождении языка. М. : Наука. 137 с.

Дата поступления: 16.05 .2016 г.

\section{REFURBISHING THE METHODOLOGY OF HISTORICAL RESEARCH \\ S. V. GORYUNKOV}

(Public regional center of cognitology, Saint Petersburg)

The article addresses the issue of scientific character of the historical mode of thinking. As seen from the empirical material, the core of the problem is that the theoretical foundation of the so-called 'principle of historicism' implicitly contains the birthmark of tautological understanding of development.

No serious discussion of this problem has so far been held, and no comprehensive theory offered. What we have is inconsistent observations of theoretical and methodological nature that a number of scientists from disparate fields have come up with. These observations are usually scattered around their highly specialized articles and monographs, or advanced by authors whose works found themselves on the periphery of their field for ideological, situational and other reasons.

As a consequence, the current historical methodology fails to produce a clear language of description. On the one hand, we face an inertial adherence to outdated premises in mass scholarly consciousness, since they are perceived as retaining at least the appearance of "scientific character". On the other hand, there is a growing interest in factual, empirically verified, knowledge, even though so far it has not received a full-fledged theoretical justification. Thus the contradiction between these two approaches is increasingly perceived as a visible manifestation of the crisis in the historical research methodology.

To overcome this crisis, we must begin with operationalization (empirical interpretation) of the language of its description. We must refurbish the theoretical and methodological instruments of history by enhancing its cognitivist power. To put it simply, the reliance on empirical data in respect of the historical dynamics of the mental and linguistic structures that should serve as a methodological alternative to the aprioristic and tautological propositions that are still offered and widely accepted to embody «the principle of historicism».

Keywords: history as discipline; methodology of history; na?ve objectivist view of history; 'principle of historicism'; empirical generalization

\section{REFERENCES}

Bertalanffy, K. L. von (1969) Obshchaia teoriia sistem - obzor problem i rezul'tatov. In: Sistemnye issledovaniia : ezhegodnik. Moscow, Nauka. 203 p. Pp. 36-37. (In Russ.).

Vernadskii, V. I. (1931). Ob usloviiakh poiavleniia zhizni na zemle. Izvestiia Akademii nauk SSSR, issue VII, Otdelenie matematicheskikh i fizicheskikh nauk, no. 5, pp. 633-653. (In Russ.).

Vernadskii, V. I. (1967) Biosfera. Moscow, Mysl'. 376 p. (In Russ.).

Vernadskii, V. I. (1975) Razmysbleniia naturalista : in 2 books. Moscow, Nauka. Vol. 1. 177 p. (In Russ.). 
Vernadskii, V. I. (1988) Filosofskie mysli naturalista. Moscow, Nauka. 522 p. (In Russ.).

Vernadskii, V. I. (1987) Khimicheskoe stroenie biosfery Zemli i ee okruzheniia. Moscow, Nauka. 339 p. (In Russ.).

Vernadskii, V. I. (1989) Nachalo i vechnost' zhizni. Moscow, Sovetskaia Rossiia. 704 p. (In Russ.).

Gadamer, H.-G. (1988) Istina $i$ metod. Osnovy filosofskoi germenevtik. Moscow, Progress. 704 p. (In Russ.).

Gadamer, H.-G. (1991) Aktual'nost’ prekrasnogo. Moscow, Iskusstvo. 366 p. (In Russ.).

Goriunkov, S. V. (1991) O sootnoshenii mifologii i ontologii (v svete idei V. I. Vernadskogo). In: Noosfera $i$ khudozhestvennoe tvorchestvo, collected articles / ed. V. V. Ivanov. Moscow, Nauka. 280 p. Pp. 88-100. (In Russ.).

Goriunkov, S. V. (2002) O germenevtike bylin. Russkaia literatura, no. 1, pp. 100-108. (In Russ.).

Goriunkov, S. V. (2014) Meta-kody kul'tury. St. Petersburg, OOO Kontrast. 304 p. (In Russ.).

Humboldt, W. von (1984) Izbrannye trudy po iazykoznaniiu. Moscow, Nauka. 398 p. (In Russ.).

Dal', V. (1996) Tolkovyi slovar' zhivogo velikorusskogo iazyka: in 4 vol. St. Petersburg, TOO «Diamant». Vol. 4. 688 p. (In Russ.).

Darwin, Ch. (1939) Sochineniia / ed. L. L. Berga, A. A. Borisiaka, N. I. Vavilova et al. Moscow ; Leningrad, Akademia nauk SSSR Publ. Vol. 3.830 p. (In Russ.).

Kassirer, E. (2002) Filosofiia simvolicheskikb form : in 3 vols. Moscow, St. Petersburg, Universitetskaia kniga. Vol. 1. 272 p. (In Russ.).

Levi-Strauss, C. (1985) Strukturnaia antropologiia. Moscow, Nauka. 536 p. (In Russ.).

Levi-Strauss, C. (2006) Mifologiki: syroe i prigotovlennoe. Moscow, ID «Fliuid». 399 p. (In Russ.).

Losev, A. F. (1983) O znachenii istorii filosofii dlia formirovaniia marksistsko-leninskoi kul'tury myshleniia. In: Alekseiu Fedorovichu Losevu: $k$ 90-letiiu so dnia rozbdeniia, sbornik statei, comp. V. V. Goguadze. Tbilisi, Tbilis. un-t Publ. 170 p. Pp. 142-155. (In Russ.).

Losev, A. F. (1993) Ocherki antichnogo simvolizma i mifologiia. Moscow, Mysl'. 959 p. (In Russ.).

Lukov, Val. A. (2008) Sub'ektnaia kul'turologiia. Informatsionnyi gumanitarnyi portal "Znanie. Ponimanie. Umenie», no. 4 [online] Available at: http://www.zpu-journal.ru/e-zpu/ 2008/4/Lukov_culturology/ (access date: 10.04.2016). (In Russ.).

Nalimov, V. V. (2011) Spontannost' soznaniia. Veroiatnostnaia teoriia smyslov $i$ smyslovaia arkbitektonika lichnosti, 3 ed. Moscow, Akademicheskii proekt; Paradigma. 399 p. (In Russ.).

Noveishii filosofskii slovar' (1998) / ed. A. A. Gritsanov. Minsk, V. M. Skakun Publ. 896 p. (In Russ.).

Ogurtsov, A. P. (1999) Sotsial'naia istoriia nauki: dve strategii issledovanii. In: Filosofiia, nauka, tsivilizatsiia / ed. V. V. Kaziutinskii. Moscow, Editorial URSS. 368 p. Pp. 63-88. (In Russ.).

Ot redkollegii (2014). In: Teoriia i metodologiia istoricheskoi nauki. Terminologicheskii slovar', ed. A. O. Chubar'ian. Moscow, Akvilon. 576 p. Pp. 5-10. (In Russ.).

Propp, V. Ya. (1976) Fol'klor i deistvitel' nost'. Izbrannye stat'i. Moscow, Nauka. 326 p. (In Russ.).

Tokarev, S. A. and Meletinskii, E. M. (1980) Mifologiia. In: Mify narodov mira: in 2 vol. Moscow, Sovetskaia entsiklopediia. Vol. 1. 672 p. Pp. 11-20. (In Russ.). 
Toporov, V. N. (1982) Pervobytnye predstavleniia o mire (obshchii vzgliad). In: Ocherki istorii estestvenno-nauchnykb znanii v drevnosti / ed. A. N. Shamin. Moscow, Nauka. 279 p. Pp. 8-40. (In Russ.).

Whitehead, A. N. (1990) Izbrannye raboty po filosofii / ed. M. A. Kissel. Moscow, Progress. 718 p. (In Russ.).

Florenskii, P. A. (1999) Sochinenia: in 4 vol. Moscow, Mysl'. Vol. 3 (1). 621 p. (In Russ.).

Freidenberg, O. M. (2008) Mif i literatura drevnosti. Ekaterinburg, U-Faktoriia. 896 p. (In Russ.).

Heidegger, M. (2006) Bytie i vremia. St. Petersburg, Nauka. 451 p. (In Russ.).

Jung, C. G. (1993) Problemy dushi nashego vremeni. Moscow, Progress; Univers. 336 p. (In Russ.).

Iakushin B. V. (1985) Gipotezy o proiskhozhdenii iazyka. Moscow, Nauka. 137 p. (In Russ.).

Submission date: 16.05 .2016$.

Горюнков Сергей Викторович - руководитель Общественного регионального когнитологического центра, член-корреспондент Петровской академии наук и искусств, академик Международной академии социальных технологий. Адрес: 197348, Россия, г. СанктПетербург, Богатырский пр., А. 7, корп. 3, кв. 261. Тел.: +7 (921) 338-86-23. Эл. адрес: RKC-alfa@mail.ru

Goryunkov Sergey Viktorovich, Head, Public Regional Center of Cognitology; Corresponding member, Petrine Academy of Arts and Sciences, Member, International Academy of Social Technologies. Postal address: Apt. 261, Bldg. 3, 7 Bogatyrskiy Prospekt, 197348 Saint Petersburg, Russian Federation. Tel.: +7 (921) 338-86-23. E-mail: RKC-alfa@mail.ru 